\title{
The Gametophytes and Embryo of Pseudotsuga Douglasii.
}

\author{
$\mathrm{BY}$
}

\author{
ANSTRUTHER A. LAWSON, PH.D. \\ Lecturer in Botany, the University of Glasgow.
}

\section{With Plates XII, XIII, and XIV.}

URING an examination of the gametophytic structure of various
genera of the Abietineae certain features in regard to Pseudotsuga Douglasii were brought to light which proved to be unusual and interesting. On account of the accumulating evidence in support of the view that the Abietineae constitute a very ancient group of the Coniferales, and especially as Pseudotsuga is one of the few genera which have not been investigated, it has been thought advisable to record these unusual features in connexion with the gametophytes of this genus.

The material was collected in Santa Clara County, California. The investigation was, for a considerable part, carried on at the Jodrell Laboratory, Royal Gardens, Kew, but was finished in the Laboratory of the University of Glasgow. For facilities afforded at the Jodrell Laboratory I am much indebted to Lieut.-Col. Prain, F.R.S., and also to Mr. L. A. Boodle, F.L S., for many kindnesses.

\section{The Male Gametophyte.}

Pollination takes place early in April or the latter part of May, and lasts for two or three weeks. The first material for the study of the microspores was collected on April 2. At this date many of the sporangia at the base of the cones had discharged their microspores, but the sporangia in the middle and upper regions of the cones were quite full of pollen. There appeared to be no difference in the state of development, however, between the microspores within the sporangia at this time, and those which had been discharged. The spores were practically globular in form, and showed a distinct and well-developed exine. Unlike Cedrus, Pinus, and many other Abietineae, there were no wings or bladder-like swellings to give buoyancy to the spore. A cross-section of a microspore at the time of pollination is 
represented in Pl. XII, Fig. I. Within the spore two degenerating prothallial cells, lying close to the spore-wall $\left(p^{\prime}, p^{\prime \prime}\right)$ were readily recognized. One of these appears as a mere film of deeply-staining nuclear substance, closely applied to the inner surface of the spore wall, while the other is represented by a small irregular mass of chromatin situated close to its neighbour but in a line towards the interior of the spore. The presence of these prothallial cells in the pollen grains, in which there are no bladder-like swellings of the exine to afford buoyancy, does not give support to the view (Robertson, '04) that a correlation exists between the survival of the prothallial cells and the winged character of the pollen.

In addition to the two prothallial cells, there are two large free nuclei within the microspore. One of these is centrally situated and is the so-called generative nucleus; the other is the tube nucleus. Both nuclei are surrounded by dense granular cytoplasm, and between the latter and the spore wall are numerous starch grains. As indicated in Fig. I all four nuclear structures lie in the same plane; that is in a row one behind the other.

The pollen-receiving device in Pseudotsuga is quite peculiar and unlike anything yet described for Gymnosperms. For some little time after pollination, the nucellus presents the form of a small protuberance with a perfectly rounded apex. The integument extends for a considerable distance beyond the nucellus. At a point immediately above the apex of the nucellus the integument bends inward in such a fashion as to partly close or narrow the micropylar canal, and then sharply bends outward again. This results in the formation of a distinct stricture midway between the apex of the nucellus and the mouth of the mieropyle. As a result of this peculiar curvature of the integument, the micropylar canal is not a straight passage of uniform width, but consists of two chambers, one immediately above the apex of the nucellus, and the other near the mouth of the mycropyle. The relative position and form of these two chambers are shown in Fig. 3, as well as the narrowness of the passage between them. The fact is also made clear in this figure that the curvature of the integument is much greater on the side nearest the ovuliferous scale.

In addition to this narrowing in the middle region of the micropyle, the integument is still further modified. It will be seen in Fig. 3 that the extremity of the integument which forms the mouth of the micropyle is folded inward. On the inner surface of this infolding extremity numerous fine hair-like processes are present. A close examination of these processes made it clear that they were not cellular in structure, but were merely outgrowths from the external walls of the epidermal cells. They serve very effectively, however, as a stigmatic surface, for during pollination the extremity of the integument is directed outward instead of inward.

It will be remembered that in nearly all of the Coniferales the pollen 
grains find a lodgement on the apex of the nucellus, and upon germination directly penetrate the nucellar tissue. This is certainly not the case with Psendotsuga. Of the numerous preparations examined I was unable to find a single case of a pollen grain that had reached the nucellus. They were invariably-and sometimes in great number-found in the upper chamber of the micropyle and frequently entangled in the hair-like processes at the mouth. They are evidently caught on the stigmatic surface when the mouth is extended, and when the extremity turns or folds inwards as shown in Fig. 3 the pollen grains find themselves enclosed in the upper chamber. It will be seen in Figs. 3 and 4 that the stigmatic processes are now all pointing backwards towards the interior of the micropyle. It is in this upper chamber of the micropyle that the pollen grains commence their germination. In Figs. 3, 4, and Io some characteristic positions of germinating grains are shown.

It will also be observed from these figures that after pollinationas a result of continued growth-the whole micropylar region of the integument bends or curves towards the ovuliferous scale. This is evidently due to the fact that growth of the integument on the side nearest the ovuliferous scale is less rapid than that on the opposite side. This irregular growth continues until-as indicated in Figs. 4 and Io-the more distal part of the micropyle lies at right angles to the long axis of the ovule.

The pollen grains remain in the upper chamber of the micropyle for a week or ten days before germination begins. This is marked first by a rupture of the exine and a slight protrusion of the pollen-tube. It was observed that the rupture of the exine and the protrusion of the pollen-tube always take place at the side of the pollen-grain directly opposite to that occupied by the two degenerated prothallial cells-that is, on the side nearest the tube nucleus. In Fig. 3 one may see the position and germinated condition of the pollen grains as they appeared on April 28.

The division of the generative nucleus evidently takes place about the time the exine is ruptured, and just before the appearance of the pollentube; for although the actual dividing stages were not found, the immediate results of this division were frequently observed. As indicated in Fig. 2 the division of the generative nucleus results in the organization of two distinct cells, one of which is considerably larger than the other. The cytoplasm of these two cells is much more dense and granular than the cytoplasm of the pollen-tube, and each is completely surrounded by a thin but sharply defined cell-membrane. The smaller of the two is the so-called stalk-cell, while the larger one is the body-cell. The tube nucleus descends with the tip of the growing tube, but the stalk- and body-cells remain in their original positions for some considerable time. This may be seen in Fig. 2.

After the conditions shown in Fig 2 the growth of the pollen-tube is quite rapid. As the tube elongates, both the body-and stalk-cells move forward 
and descend slowly in the wake of the tube nucleus. In their movement down the tube both these structures enlarge to three or four times their original size. But the body-cell-which during these stages was always found in advance of the stalk-cell-increases in size at a much greater rate than the latter, so that before they have advanced very far into the tube the one is more than twice the size of the other. These conditions are indicated in Fig. 5.

Owing to the large number of pollen-tubes that were found growing in the upper chamber of the micropyle, and also owing to the fact that there was no tissue in the way to offer resistance to their growth, the tubes elongated towards the nucellus in a more or less irregular fashion. These circumstances made it impossible to obtain a section showing the full length of any one tube. On comparing the series of sections from which Fig. 4 was drawn it was evident that the tubes folded about each other in such a fashion as to form a complex tangle as they elongated. Fragments of at least five different tubes are shown in Fig. 4. Fig. 6 represents a portion of a section of a young tube with the body-cell descending towards the tip. It will be observed from this figure that the nucleus of the body-cell has enlarged enormously. The entire cell becomes very much elongated with the nucleus in advance of the drawn-out cytoplasm. At this time the membrane enveloping the body-cell becomes exceedingly thin, and in many cases could only be distinguished by careful focusing. Its location, however, could always be made out as the line separating the coarse granular cytoplasm, characteristic of the body-cell, from the more delicate and less dense cytoplasm of the tube.

In Fig. 7 is represented the condition of the body-cell at a time when the tip of the tube has traversed about half the length of the micropylar canal. As it was possible to obtain only short segments of the pollen-tubes in longitudinal section I was unable to determine the relative positions of the stalk- and body-cells at this time. There was some evidence, however, that the stalk-cell was now in advance of the body-cell as happens in Pinus (Ferguson, '04), but with so many segments of different tubes in the micropyle one could not be certain that one was following the same tube in serial sections.

The actual division of the body-cell was not observed, but after a study of the chromatin and the cytoplasm immediately surrounding the nucleus, it seemed quite certain that this division takes place before the tip of the pollen-tube reaches the nucellus. In Fig. 7 the nucleus is represented very much enlarged-its diameter being nearly equal to the width of the pollentube. A large, deeply-staining nucleolus was always present, and the chromatin at this time was in the so-called reticulum stage. This reticulum seemed to be made up of very delicate threads which crossed and anastomosed with one another in such a fashion as to give the appearance of 
a network. Suspended in this network-especially at the angles where the threads crossed one another-numerous irregularly-shaped granules were observed. Although these granules were undoubtedly chromatin, and although they stained more deeply than the thinner portions of the threads which constitute the reticulum, it was quite impossible to determine how much of the thread consisted of chromatin, and how much of linin. Indeed, as far as one could judge from its affinity for stain, the entire reticulum seemed to be made up of chromatin threads-staining less deeply in the thinner places and more deeply at the points where the threads intersected one another.

Accompanying the enlargement of the nucleus and the organization of the loose chromatic reticulum as shown in Fig. 7 , the approach of nuclear division was also indicated by changes in the cytoplasm. Immediately surrounding the nucleus, the cytoplasm becomes densely granular until a more or less definite zone is differentiated-this being the first step towards the organization of the achromatic spindle. Fig. 8 shows a slightly older stage where the dense zone of cytoplasm becomes still further differentiated into definite but very fine spindle fibrils. It will be observed that these fibrils at first appear only on one side of the nucleus-the remaining surface being quite free of them. The details of this spindle in Pinus have been carefully worked out by Miss Ferguson ('04), and here this same peculiarity of the early stages of spindle-formation has been observed.

From a study of Fig. 8 it will be seen that during the differentiation of the spindle fibrils the nucleus has lost its reticular structure. The chromatin threads no longer form a network, but become much thicker, more granular, and stain much more deeply than in the stage represented in Fig. 7. The reticulum has given rise to the spireme.

While the mature spindle of the dividing body-cell was not found, sufficient observations on the early stages of spindle-formation were made to convince me that no structures which could be interpreted as blepharoplasts were present during the organization of the sperm nuclei. This, however, is what one would naturally expect, for in the Abietineae as well as in all other Coniferales the last vestige of the motility of the male gamete disappeared with the specialization of the pollen-tube as a means of conveying the sperm nuclei into the egg. The next stage observed in Pseudotsuga was that at the time of fertilization. The two sperm nuclei, accompanied by the tube- and stalk-nuclei, were found just inside the archegonium. As in Pimus (Ferguson, '04, Blackman, '98, Coulter and Chamberlain, '01), Abies (Miyake, '03), Tsuga (Murrill, '00) and Picea (Miyake, '03), these nuclei are of unequal size - the functional one being quite twice the size of its neighbour. These are represented in Fig. $36^{1}$

1 The meaning and causes of this inequality of the sperm nuclei have already been fully discussed in this journal (Lawson, Ann. Bot., vol. xxi, No. LXXXII, 1907, pp. 292-3). 
Compared with Pinus, Torreya, Cephalotaxus, and certain other Conifers, the time required for the complete development of the male gametophyte is very short. The sperm nuclei are organized, and fertilization takes place within sixty days after pollination.

The number and history of the nuclear structures which constitute the male sexual generation in Pseudotsuga are in all essentials similar to those of Pimus and Picea, the only two genera of the Abietineae in which a full account has been recorded.

\section{The Female Gametophyte.}

The collection of material was commenced too late to allow of a study of the development of the megaspores. In the ovules taken March 30 the megaspore was not only fully organized but had already germinatedits nucleus having undergone repeated free division. The earliest stage found is represented in Fig. 9. It may be seen from this figure that the functional megaspore is very much enlarged, and at the micropylar end are at least two flattened structures which I interpret as the remains of disintegrating functionless spores. These remains were so far disintegrated that it was impossible to distinguish a membrane between them. They appeared to be two fragmented nuclei. They were, however, separated from the functional spore by a definite membrane. It was impossible to say whether a fourth spore had been formed. The position of the three observed, however, makes it clear that, whether three or four spores are originally formed, they are arranged in an axial row.

The interior of the functional megaspore consisted mainly of cell-sap contained within two or three large vacuoles. In proportion to its size comparatively little cytoplasm was present, and this was found mainly at the periphery and surrounding the free nuclei. Three of the free nuclei are to be seen in Fig. 9. The spore wall could be made out as a very thin delicate membrane, apparently of a plasmatic nature.

Completely enveloping the growing megaspore, and in close contact with the spore membrane, there is a layer of large sporogenous-like cells. These large cells form practically a single layer, although at places, as indicated in Fig. 9, they may appear two cells deep. They are at least three or four times the size of the ordinary surrounding cells of the nucellus, and as their cytoplasm is very highly granular, and their nuclei large and deeply staining, the entire layer has the characteristic appearance of sporogenous tissue.

From the fact that these cells are so closely associated with the young growing prothallium, and from the fact that they are so fully charged with nutritive substances, one can only conclude that they are nutritive in function. They constitute an early stage in the formation of the so-called 'spongy tissue ' or 'tapetum' which has been frequently described for Pinus and other 
Gymnosperms. The nature and function of these cells has been discussed at some length by Miss Ferguson (1903-4). In her paper on Pimus this writer rejects the idea that these cells are sporogenous on the ground that 'the divisions in this tissue are according to the typic method, and present the number of chromosomes characteristic of the sporophyte'. It should be remembered, however, that the haploid phase does not appear until the division of the mother-cell, and that there may be more than one generation of diploid archesporial cells. In his work on Stangeria, Lang ('00) describes these cells as a 'sporogenous group', the outermost of which 'form a more definite tapetal layer'. Arnoldi ('01) also describes in Cunninghamia an 'archesporial tissue' surrounding the young embryo sac.

From what we know of the development and nature of the 'spongy tissue' in the Gymnosperm ovule in the various types studied, there are good reasons for believing that it is not only tapetal in function but is also archesporial in origin. My belief in this regard has been very much strengthened after a study of the development and behaviour of this tissue in Pseudotsuga. All of the facts point to the conclusion that it consists of archesporial cells which do not reach or go beyond the mother-cell stage.

Although in Psendotsuga the tapetum at an early stage consists of a single layer of cells closely packed together, it eventually becomes several layers thick. It increases with the growth of the young prothallium. This increase and growth are, however, not very rapid. In Fig. 10 the prothallium is represented in the parietal multinucleate condition surrounded by several layers of tapetal cells. It will be observed that the latter are no longer closely packed together, but are arranged quite loosely with numerous intercellular spaces. It was also observed at this time that the megaspore wall appeared as a sharp well-defined membrane of measurable thickness.

From the time of the free nuclear stage represented in Fig. 9 to the multinucleate parietal condition represented in Fig. Io four weeks have elapsed. The development is slow but not interrupted by a resting period as is the case with Pinus (Ferguson, '04). The parietal condition is represented in Fig. II. This is some little time before the primary prothallial cells are formed. It will be seen that there is a very large central vacuole which keeps the cytoplasm closely pressed against the megaspore membrane. As illustrated in Fig. I 2 the cytoplasm consists of a thin film no wider than the diameter of one of the free nuclei which are distributed at regular intervals in it. The regular distribution of the nuclei is probably due to the fact that they have undergone their last free division and are preparing for the mitosis which will result in the formation of walls between them. A stage immediately following this division is represented in Fig. I3. It will be observed that there is now a cell-wall separating each nucleus from its neighbour, and that the cells thus formed are open on the inside and freely exposed to the sap of the central vacuole. 
These are the first or primary cells of the prothallium which were first described by Mlle. Sokolowa ('90) as alveoli, and which have since been found in many other Gymnosperms. The nuclei of the primary cells were nearly always found occupying a position at the surface of the cytoplasm nearest the central vacuole. In Fig. I 5 is represented a group of these cells as seen in a section taken at right angles to the dividing walls. It was observed that these walls were nearly always six in number for each cell, and were arranged about the respective nuclei in such a fashion as to give the appearance of a regular symmetrical mosaic.

Rapid development immediately follows the organization of the primary prothallial cells. These structures elongate in an inward direction, and encroach upon the central vacuole in the manner already described for other Conifers (Sokolowa, '90; Arnoldi, '01 ; Coker, '04; Ferguson, '05 ; Lawson, '04 and '07). This is represented in Fig. I6. The later stages in the formation of the permanent prothallial tissue were not found, but it was observed that free nuclear division may proceed in the primary cells for some time before cross-walls are formed. Some cross-walls were, however, found at quite an early period. The multinucleate condition of the primary prothallial cells may be seen in Fig. I6.

During these stages in the development of the prothallium the megaspore membrane becomes decidedly thicker and much more conspicuous. Its structure in the mature condition is very similar to that described for Pinus (Thomson, '05). The fibrillae of the exosporium, however, seemed to be longer, finer, and more regularly arranged than that of Pimus. From measurements taken it was found that the membrane varied in thicknessbeing thicker at the base of the prothallium than along the sides, its approximate average thickness being $4.5 \mu$ (Fig. I4). At a plane almost level with the base of the archegonia the membrane thins out rather abruptly, and from this region to the very apex of the prothallium no trace of the membrane could be detected. A section of the prothallium showing this is represented in Fig. I7. It will be seen from this that the archegonial region extends beyond the limits of the spore. In its distribution the megaspore membrane suggests that of Larix (Thomson, '05), but is quite unlike that of Tsuga, where, according to my own observations, the membrane completely surrounds the archegonial region.

\section{The Archegonia.}

The young archegonia make their appearance during the second and third week of May. The earliest stage observed was that where the primary neck-cell had already been cut off from the central cell, and the latter had enlarged to several times the size of the neighbouring sterile prothallial cells. From the position of these two cells it was quite evident that the archegonial initials originate as superficial cells at the apex of the prothallium, as in 
Pinus, Picea, Abies, and other Conifers. The primary neck-cell shows little, or no further increase in size but very soon divides by an anticlinal wall. The two cells thus formed may undergo division by periclinal walls to form two tiers of cells in the neck. In many archegonia, however, especially in the later stages of development, but a single tier of cells could be found. This confirms the observations of other writers (Murrill, '00; Coulter and Chamberlain, '01; Coker, '02 ; Ferguson, '04), that the variation in the number of neck-cells is quite common among the Coniferales.

The central cell increases in size quite rapidly and its elongation is directed towards the centre of the prothallium. It is at first vacuolate, with a large nucleus and granular cytoplasm. Later, the small vacuoles become so numerous that the cytoplasm takes on a frothy appearance quite like that of certain other Abietineae (Miyake,' 03) and Cephalotaxus (Lawson, '07).

At a very early stage in the development of the central cell a single layer of jacket cells becomes organized. This nourishing sheath appeared in all respects similar to those already fully described for other Abietineae. It is, however, a significant fact that the original cells of the jacket in many of the Abietineae make their appearance simultaneously with the archegonial initials. In certain cases it is only their relative position which allows us to distinguish between the primary jacket cells and the archegonial initials at these very early stages.

Stages in the development of the central cell are shown in Figs. I8, I9, 20, 2I. The nucleus, although very large, remains in the vicinity of the neck. The sterile tissue at the apex of the prothallium continues to grow forward, leaving a free passage to the neck of each archegonium. This passage or archegonial chamber is, however, not very deep-resembling more closely the conditions found in Pinus, Picea, and Larix than those described for Tsuga (Murrill, '00).

The largest number of archegonia found in one prothallium was six. The number seems to vary from four to six. Four, however, was the commonest number met with. They are situated quite closely together (Figs. 27 and 28 ), there being very little sterile tissue between them. Although the necks are separated from one another by a considerable amount of tissue, they may come in contact with one another in the middle region where they are widest. This condition may be seen in Fig. 28. This figure also illustrates the fact that the archegonia are much longer in proportion to their width than is the case in Pinus, Picea, Larix, or Tsuga. The form they present in cross-section is shown in Fig. 27.

The archegonium reaches nearly its mature size before the central nucleus-which retains its position near the neck-cells-shows any further activity. But from the material collected upon June 3 many evidences of nuclear activity were found in the central cell. Transition-stages from the reticulum to the spireme, and from the spireme to the definite chromosomes, 
were frequently met with. While these changes in the form of the chromatin were in progress, it was observed that the cytoplasm immediately surrounding the nucleus was also undergoing a change of structure. From the series of stages found it was evident that on the anterior and posterior (in regard to the long axis of the archegonium) surfaces of the nucleus, the cytoplasm becomes differentiated into delicate kinoplasmic threads. These threads or fibrils are the first indications of the achromatic spindles. At the two places where they appear the nuclear wall breaks down and the fibrils extend into the nuclear cavity, and there come in contact with the chromosomes. The details of the further organization of the ventral canal spindle have been so fully described for Picea (Miyake, '03) and Pinus (Ferguson, '05), and agree so closely with my own observations on Pseudotsuga, that a further description is unnecessary.

In Pseudotsuga - as in all other Abietineae where the development of the egg has been observed-a definite membrane is formed which separates the ventral canal cell from the egg. The position of this membrane is shown in Figs. $23,24,25$, and 26 . It will also be observed from these figures that the nucleus of the ventral canal cell immediately shows signs of disintegration, while the nucleus of the egg descends towards the centre of the archegonium and becomes enormously enlarged. From the drawn-out appearance of the cytoplasm between the egg-nucleus and the ventral canal cell it would appear that the descent of the enlarged nucleus is quite rapid. A very characteristic appearance of the archegonium and the condition of the cytoplasm is shown in Fig. 26. The membrane of the ventral canal cell persists up to the time of fertilization. The phylogenetic importance of this membrane has already been discussed in a previous memoir (Lawson, '07). Its presence in the Abietineae and its entire absence in the Cupressineae, Taxodineae, and Taxineae is certainly significant.

In Fig. 28 are represented two mature archegonia ready for fertilization.

\section{Fertilization.}

It will be remembered that the pollen-tubes have attained a great length before they reach the nucellus. In this regard Pseudotsuga is quite unlike any other of the Abietineae in which the stages of fertilization have been studied. It is the rule among the Abietineae that the pollen is deposited directly upon the apex of the nucellus and the tissue of the latter is penetrated immediately by the growing tubes. It is remarkable that there should be this difference in the behaviour of the pollen-tubes of forms that are so closely related. It nevertheless demonstrates how plastic a structure the pollen-tube really is, and how unreliable is the evidence it affords for phylogenetic purposes. It will be remembered how unusual are the growth and distribution of the pollen-tubes in Sequoia (Lawson, '04). Here also there is a very early growth, and their distribution, although irregular, is 
established before the prothallium is formed. The conditions in Pseudotsuga, however, suggest those in the Araucarineae (Thomson, '05 ; Lopriore, '05), but unlike the latter there are no additional free nuclei in the tubes. The development of the pollen-tubes in a position so far removed from the nucellus is no doubt a specialization to meet the peculiar pollen-receiving device.

Correlated with the position of the pollen-tubes in Pseudotsuga there is an early disintegration of the tissue of the apex of the nucellus. The cells in this region of the nucellus separate from one another in places, and there appears to be a general breaking-down or dissolving of the tissues in advance of the descending pollen-tubes. These latter structures, therefore, find no obstructions in their path. There is no firm tissue to penetrate before reaching the archegonial chambers. Indeed, at the time of fertilization the apex of the nucellus is completely broken down, and we find an appearance very unlike that of Pinus and the majority of other Coniferales where the nucellus persists for some time after fertilization.

As in other Abietineae the archegonia are so arranged that the necks are separated from one another by sterile prothallial tissue and each archegonium has its own archegonial chamber. By this arrangement the tip of the pollen-tube enters an archegonial chamber and its entire contents are discharged into the egg. It is therefore possible for one pollen-tube to fertilize but a single archegonium. It was noticed that the depth of the archegonial chambers was not as great as that in $T$ suga, and the number of neck-cells is also less (Murrill, '00). In fact there is a considerable difference in the appearance of the archegonial group of the two genera. This seems to be in harmony with Jeffrey's ('05) conclusions that Pseudotsuga is more closely related to Larix, Picea, and Pimus than it is to Abies, Psendolarix, Cedrus, and Tsuga.

By the time the egg nucleus reaches its central position, after the organization of the central canal cell, it becomes very much enlarged. This enlargement is indicated in Figs. 29, 30, and 32. During this period the egg cytoplasm loses its 'frothy' or vacuolate appearance, and becomes very coarsely granular by the presence of numerous so-called ' proteid vacuoles'.

As the egg-nucleus approaches its mature size, and prepares for fertilization it takes on a very extraordinary appearance due to the presence of several dense masses of cytoplasm which seem to project at intervals into the interior of the nucleus. As a matter of fact these masses do not project into the nucleus but are contained in small indentations or pockets which give the nuclear membrane a very irregular outline in the manner shown in Fig. 3 $\mathrm{I}$. These masses of dense cytoplasm proved to be quite interesting and important because it was found that one or more of them take, eventually, an active part in the formation of the fibrils of the spindle immediately following fertilization. This has thrown considerable doubt on the statement repeatedly made (Blackman, '98, Murrill, '00, Ferguson, '05, and others) 
that the fibrils of the first cleavage spindle are differentiated out of nuclear substance. The following observations I think will show that these fibrils are of cytoplasmic origin. These cytoplasmic masses first appear very soon after the ventral canal cell is organized, and while the egg-nucleus is comparatively small. The cytoplasm surrounding the young egg-nucleus becomes more dense, forming a more or less definite zone, much as in the early spindleformation stages in the Angiosperms. This zone, however, owing to the very rapid growth and distension of the nucleus, becomes interrupted at intervals. As a result of this continued rapid growth we find, instead of a zone, numerous patches or masses of cytoplasm which become quite separated from one another, and which stain more deeply than the surrounding cytoplasm. These dense masses - which soon show a finely fibrous structure-being in contact with the nuclear membrane, offer a resistance to the growth of the nucleus. The osmotic pressure within-which no doubt causes the enlargement of the nucleus--forces the membrane between these dense masses, and almost completely envelops them. The result is that the contour of the nucleus becomes interrupted by several infolding pockets, each of which contains a dense mass of cytoplasm which is distinctly fibrous in structure. On account of their distribution they could be studied to much better advantage in cross- than in longitudinal-sections. A characteristic appearance of a cross-section of a nucleus at this time is shown in Fig. $3 \mathrm{I}$.

Very similar pockets of cytoplasm have been noted and figured in Pinus by Ferguson ('05) and in Tsuga by Murrill ('00), but neither of these writers mentions the fact, although it is clearly demonstrated in their figures, that a considerable amount of cytoplasm is carried into the eggnucleus at the time of the fusion of the sex nuclei. Indeed, both of these writers describe the spindle fibrils of the first mitosis of the pro-embryo as originating from transformed nuclear substance. The chromatic contents of the egg-nucleus at maturity are quite like that of Pinus which has been described by Blackman ('98) and Ferguson ('05), as is shown in Fig. 30. Immediately before fusion the chromatin becomes collected near the centre of the nucleus in the manner indicated in Fig. 32. Although the actual first contact of the male nucleus with the egg-nucleus was not observed, the stages immediately following were found in several preparations. One of these stages is shown in Fig. 33. It became evident from this figure that there is no resting period of the fusion-nucleus, for the first segmentation spindle is already in process of formation. Although the chromosomes could be observed quite easily, it was impossible to distinguish the male group from the female. As shown in Fig. 33, the first spindle of the pro-embryo is formed within the area bounded by the membrane of the egg-nucleus. There seems little doubt that its fibrils are formed out of the dense masses of cytoplasm carried in by the male nucleus, and not out of nuclear substance. 


\section{THE Embryo.}

With the organization of the first segmentation spindle, the membrane of the fusion-nucleus becomes very indefinite, and gradually fades out completely. As indicated in Figs. 34 and 35, the axis of the spindle comes to lie nearly at right angles to the long axis of the archegonium. During the period of the disorganization of the nuclear membrane an interesting observation was made in connexion with the numerous nucleoli-like bodies which are so abundant in the mature egg-nucleus, and from which the chromatin proper becomes segregated. As shown in Fig. 35, these granules, which stain like chromatin, collect at one side of the first spindle, and numerous kinoplasmic threads develop among them as if a second spindle were in process of formation. These threads show all the characteristics of regular spindle fibrils, especially those found in the early stages of spindle-formation. Whether this second pseudo-spindle ever develops farther I am unable to say, but it is certainly a point of cytological interest that these discarded chromatin-like granules should become associated with kinoplasmic threads as the chromosomes do in the regular spindle. The behaviour of these granules would suggest a close relationship with chromatin.

The result of the division of the fusion-nucleus is indicated in Fig. 37. The daughter-nuclei remains in the upper part of the egg until the second mitosis takes place. The four free nuclei of the pro-embryo now pass to the base of the archegonium and are found in the positions represented in Figs. 38 and 39. These early stages in the development of the embryo, as well as the later ones, are essentially as in Pimus. The free nuclei enlarge considerably as they descend towards the base of the egg and become enveloped by dense granules of cytoplasm. The archegonium thus becomes differentiated into two regions-a basal nutritive region containing the pro-embryo, and an upper clearer region which is not so rich in foodgranules. This differentiation is, however, not so clearly marked as in the Cupressineae or in Cephalotaxus (Lawson, '07). The four free nuclei now at the base of the archegonium undergo further division. The latter, however, result in the formation of walls between the nuclei as shown in Fig. 40. Eventually there are three tiers of cells and a tier of free nuclei. The uppermost of these tiers becomes the 'rosette', the middle tier becomes the suspensors, and the end tier the embryo proper.

By the rapid elongation of the suspensor cells the embryo is carried deep into the tissue of the prothallium. This is shown in Fig. 4I. Associated with the elongation of the suspensors a peculiar differentiation of the contents of the base of the archegonium was observed. The cytoplasm in this region becomes replaced by a homogeneous mucilaginous substance which apparently acts as a resisting plug to the growing suspensors. 
Coker ('02) reports a similar structure in connexion with the suspensors in Podocarpus. In the latter case, however, Coker describes this plug as cellulose. The suspensor plug in Pseudotsuga failed to give the cellulose reactions. It is more probably mucilaginous in composition. The position and evident function of this plug is brought out in Fig. 42.

\section{SumMARY AND CONCLUSIONS.}

The microspore at the time of pollination is globular in form and differs in appearance from that of the majority of other Abietineae in the entire absence of bladder-like appendages.

The mature microspore contains four cells. Two of these are represented by the fragmented remains of two vestigial prothallial cells, and the other two represent the tube and generative cells respectively.

Owing to the peculiar form of the micropyle, which has a stigmatic surface at the mouth, the pollen grains fail to reach the apex of the nucellus, but are caught at the mouth of the micropyle and here germinate.

This pollen-receiving device and the formation of pollen-tubes so far removed from the nucellus is unlike anything yet reported for the Abietineae, and is evidently a novelty as far as the Gymnosperms are concerned.

With the first appearance of the pollen-tube the generative nucleus divides, and as a result of this division two distinct cells are organized, one of which is considerably larger than the other. These are the body- and stalk-cells respectively.

The pollen-tubes grow down the micropylar canal and attain a considerable length before the nucellus is reached.

The tissue of the apex of the nucellus disintegrates in advance of the approaching pollen-tubes, so that the latter structures find little or no obstruction in their path towards the archegonial chambers.

The division of the body-cell results in the formation of two male nuclei of unequal size.

The entire nuclear contents of a pollen-tube are discharged into one archegonium.

There are probably three megaspores resulting from a single mothercell. Two of these are abortive and one functional.

Upon the enlargement of the functional megaspore free nuclear division takes place, and this is followed by the formation of a large central vacuole.

Completely enveloping the growing megaspore there is a single layer of large sporogenous-like cells which are closely packed together. This layer of cells, although single at first, soon becomes several layers thick, and eventually becomes quite loose and sponge-like-with numerous intercellular spaces - as the young prothallium increases in size. This tissue is regarded as sporogenous in origin and tapetal in function.

The megaspore membrane makes its appearance at a very early period, 
and although quite thin at first it increases in thickness with the growth of the prothallium, and eventually becomes very conspicuous. In the mature stages it surrounds the prothallium except in the region of the archegonia. In this region it is entirely absent, and in this regard differs quite markedly from Tsuga.

With the increase in the size of the central vacuole, and the consequent formation of the parietal layer of cytoplasm, free nuclear division continues for some time.

The parietal layer now increases in thickness, and the primary prothallial cells are formed in the ordinary way.

These latter structures elongate in an inward direction, and gradually close the central vacuole. Free nuclear division now takes place within the primary prothallial cells, before cross-walls are formed to organize permanent prothallial tissue.

The archegonia originate as superficial cells at the apex of the prothallium.

They are generally four in number, and each is enveloped by a single layer of nourishing jacket-cells. There are generally two tiers, but frequently a single tier of neck-cells.

The archegonia are separated from one another-especially in the region of the necks-by several layers of sterile prothallial cells, and each is provided with a separate archegonial chamber.

A distinct ventral canal-cell is formed as a result of the division of the central cell.

The membrane of the ventral canal-cell persists up to the time of fertilization.

The fusion of the sex nuclei takes place in the middle of the archegonium. The female is many times the size of the male.

The first segmentation-spindle is formed within the area bounded by the membrane of the fusion-nucleus. It is, however, of cytoplasmic origin. One or more dense masses of cytoplasm are carried into the egg-nucleus by the sperm-nucleus.

The first division is very soon followed by a second, and the four free nuclei thus formed pass to the base of the archegonium.

After the division that follows, cell-walls are formed separating the nuclei.

Eventually the pro-embryo consists of three tiers of cells and one tier of free nuclei. The lowermost of these becomes the embryo proper. The middle one becomes the suspensor, and the next one the rosette.

As the suspensors elongate, the cytoplasm in the base of the archegonium becomes replaced by a mass of mucilaginous substance which acts as a plug to prevent the suspensors from growing forward.

The account here given of the gametophytes of Pseudotsuga makes it 
clear that this genus is not closely related to Tsuga. And considering the state of development of the various vestigial and semi-vestigial structures present, the view that the Abietineae are the most ancient group of the Coniferales is very much strengthened.

\section{Literature Cited.}

A RNOLDI, W. ('01): Beiträge zur Morphologie einiger Gymnospermen: V. Weitere Untersuchungen uiber die Embryologie in der Familie der Sequoiaceen. Bull. Soc. Imp. Nat. Moscou, I 90I.

Blackman, V. H. ('98): On the Cytological Features of Fertilization and Related Phenomena in Pinus silvestris, L. Phil. Trans. Roy. Soc., cxc, p. 395.

Chamberlain, C. J. ('06): The Ovule and Female Gametophyte of Dioon. Bot. Gaz., xlii, p. $32 \mathrm{I}, 1906$.

Coker, W. C. ('02): Notes on the Gametophytes and Embryo of Podocarpus. Bot. Gaz., xxxiii, p. 89 . ('03): The Gametophytes and Embryo of Taxodium. Bot. Gaz., xxxvi, pp. I-27 and II $4-40$.

('04): On the Spores of Certain Coniferae. Bot. Gaz., xxxviii, p. 206, I904.

Coulter, J. M., and Chamberlain, J. C. ('01) : Morphology of Spermatophytes, Part I. New York, I90I.

Coulter, J. M., and Land, W. J. G. ('05): Gametophytes and Embryo of Torreya taxifolia. Bot. Gaz., xxxix, p. I6r, 1905 .

Dixon, H. N. ('94): Fertilization in Pinus silvestris. Ann. Bot., viii, p. 2 I.

Ferguson, M. C. ('01): The Development of the Pollen-tube and the Division of the Generative Nucleus in certain species of Pinus. Ann. Bot., xv, p. 193. Bot., xv, p, 435 .

Hirase, S. ('95): Études sur la fécondation et l'embryogénie du Ginkgo biloba. Jour. Coll. Sci. Imp. Univ. Tokyo, viii, p. 307.

Ikeno, S. ('96): Das Spermatozoid von Cycas revoluta. Bot. Mag. Tokyo, x, p. $3^{67}$.

Jefrerey, E. C. ('03 and '05): Comp. Anatomy and Phylogeny of the Coniferales. Part I, Sequoia; Part II, Abietineae. Mem. Boston Soc. Nat. Hist., vols. 5 and 6.

Lawson, A. A. ('04): The Gametophytes, Archegonia, Fertilization, and Embryo of Sequoia sempervirens. Ann. Bot., xviii, no. lxix, p. I, I904.

('04): The Gametophytes, Fertilization, and Embryo of Cryptomeria japonica. Ann. Bot., xviii, no. lxxi, I904.

('07): The Gametophytes, Fertilization, and Embryo of Cephalotaxus drupacea. Ann. Bot., xxi, no. lxxxi, I907.

('07): The Gametophytes and Embryo of the Cupressineae with special reference to Libocedrus decurrens. Ann. Bot., xxi, no. 1xxxii, 1907 .

LANG, W. H. ('00): Studies in the Development and Morphology of Cycadian sporangia. II. The Ovule of Stangeria paradoxa. Ann. Bot., xiv, no. liv, I90o.

Lopriore, G. ('05): Ueber die Vielkernigkeit der Pollenkörner und Pollenschläuche von Araucaria Bidrvillii. Ber. d. Deutschen Bot. Gesellschaft, xxiii, p. 335 .

Miyake, K. ('03): On the Development of the Sexual Organs and Fertilization of Picea excelsa. Ann. Bot., xvii, p. 66.

('03): Contribution to the Fertilization and Embryogeny of Abies balsama. Beihefte zum Bot. Cent., xiv, p. I34, I903.

Murrill, W. A. ('00): The Development of the Archegonium and Fertilization in the Hemlock Spruce (Tsuga canadensis). Ann. Bot., xiv, p. $5^{8} 3$.

Robertson, A. ('04): Spore formation in Torreya Californica. New Phyt., iii, p. 133, 1904. ('04): Studies in the Morphology of Torreya Californica. New Phyt., iii, p. 205, I904. 
Sokolowa, M ${ }^{\text {lle }}$ C. ('90): Naissance de l'endosperme dans le sac embryonnaire de quelques Gymnospermes. Bull. Soc. Imp. Nat. Moscou, 1890 (I891), p. 446.

Stopes, M. C., and FUjir, K. ('06): The Nutritive Relations of the surrounding Tissues to the Archegonium in Gymnosperms. Beihefte zum Bot. Cent., Bd. xx, Heft I, I906.

Thomson, R. B. ('05): The Megaspore-membrane of the Gymnosperms. Univ. Toronto Studies, Biol. Series, iv, 1905 .

\title{
EXPLANATION OF FIGURES IN PLATES XII, XIII, AND XIV.
}

\author{
Illustrating Dr. Lawson's paper on Pseudotsuga Douglasii.
}

All figures were drawn with the aid of the Camera Lucida.

Fig. I. A cross-section of a microspore before pollination, showing the generative nucleus, the tube-nucleus, and two degenerating prothallial nuclei. April 2.

Fig. 2. A longitudinal section of a young pollen-tube, showing the body-cell $(B)$, the stalk-cell $(S)$, and two degenerating prothallial cells $\left(\mathrm{P}^{\prime}, \mathrm{P}^{\prime \prime}\right)$. April 28.

Fig. 3. A longitudinal section of an ovule some time after pollination, showing the upper expanded region of the micropyle with a 'stigmatic' surface, and in which two germinating microspores are seen. April 28.

Fig. 4. The same at a later stage, showing numerous pollen-tubes growing from the distal or expanded end of the micropyle towards the nucellus. May 23 .

Fig. 5. A pollen-tube soon after the division of the generative nucleus, showing the stalk- and body-nuclei and the tube-nucleus. May 3 .

Fig. 6. A pollen-tube at a later stage, showing the body-nucleus advancing towards the tip of the tube. May 23.

Fig. 7. The body-cell as it lies near the tip of the pollen-tube. May 23.

Fig. 8. The same at a later stage. The body-nucleus is preparing for division. May 23 .

Fig. 9. A longitudinal section through the sporogenous region of a megasporangium, showing one large functional megaspore which has already germinated, and two very small abortive megaspores. A distinct layer of large cells, the tapetum, surrounds the megaspores. March 30.

Fig. I0. A longitudinal section through an ovule, showing the functional megaspore and the tapetum considerably enlarged. The young prothallium within the megaspore consists of a thin parietal layer of cytoplasm in which numerous free nuclei are distributed, and a large central vacuole. A distinct megaspore-membrane is already quite visible at this stage. April 28.

Fig. II. The young prothallium shown in Fig. Io more highly magnified. April 28.

Fig. I2. A small portion of the parietal layer of cytoplasm, showing the relative size of the free nuclei. April 28.

Fig. I3. A portion of a young prothallium at a later stage, showing the formation of the first or primary prothallial cells. These primary cells have no walls on the inner side exposed to the central vacuole. The megaspore membrane shows a considerable increase in thickness at this stage. April I6.

Fig. I4. A portion of the periphery of a mature prothallium, showing the structure of the megaspore membrane at this stage. May 23 .

Fig. 15. A small portion of a section of a very young prothallium, showing the formation of the primary prothallial cells. The section is taken parallel to the inner or open surfaces of the primary cells. April I6.

Fig. 16. A longitudinal section through the lower or sterile end of a young prothallium, showing the primary prothallial cells very much elongated, and growing inward and encroaching upon the space occupied by the central vacuole. April $\mathbf{6} 6$.

Fig. I7. A section through a portion of the archegonial end of a mature prothallium, showing the gradual tapering off of the megaspore membrane in the region of the archegonia, and the entire 
absence of the membrane at, and for a considerable distance back of, the apex of the prothallium. June 3 .

Fig. 18. A longitudinal section of a young archegonium, showing the central cell, two neckcells, and a single layer of jacket-cells. May $\mathbf{I} 7$.

Fig. 19. The same at a later stage, showing the frothy appearance of the cytoplasm of the central cell. May 20.

Fig. 20. The same at a still later stage, showing the central nucleus in the region of the neck and preparing for division. May 23 .

Fig. 2I. The same at a still later stage, showing the position of the central nucleus at the time of spindle-formation. June 3 .

Fig. 22. The nucleus of the central cell undergoing division. June 3 .

Fig. 23. A later stage of the same. The central-canal nucleus is completely separated from the egg-cell by a distinct cell membrane. June 3 .

Fig. 24. A later stage of the same, showing the degeneration of the ventral canal nucleus and a great increase in the size of the egg-nucleus. June 3 .

Fig. 25. The same at a still later stage. The ventral canal nucleus has become fragmented, and the egg-nucleus has continued to increase in size, and has begun to move back towards the centre of the archegonium. The spindle fibrils stretching between the two cells are still visible. June 3 .

Fig. 26. The egg-nucleus has reached an enormous size, and occupies a position near the central region of the archegonium. Its movement from its original position near the ventral canal cell is clearly indicated by the structure and drawn-out appearance of the cytoplasm in the forward half of the egg. June 3 .

Fig. 27. A cross-section near the apex of a mature prothallium, showing four archegonia. Each archegonium is enveloped by a complete single layer of jacket-cells, and each is separated from its neighbour by sterile tissue. May Io.

Fig. 28. A longitudinal section through the apex of a mature prothallium, showing the appearance of the archegonia just before fertilization. June 3 .

Fig. 29. A longitudinal section of the egg-nucleus at a stage soon after the organization of the ventral canal cell. The egg-nucleus has attained a considerable size. Very close to the nucleus membrane there is an accumulation of several masses of very dense cytoplasm. June 3 .

Fig. 30. A later stage of the same, showing the egg-nucleus more than twice the size of that shown in Fig. 29. The dense masses of cytoplasm are larger and more numerous. June 3.

Fig. 31. The same, showing how much more numerous the dense masses of cytoplasm appear in cross-section. By the distending of the nuclear membrane outward between the dense masses of cytoplasm, the latter resemble small pockets projecting towards the interior of the nucleus. June 3 .

Fig. 32. A longitudinal section of the egg-nucleus showing the segregation of the chromatin from the other nuclear substances. June 3 .

Fig. 33. The same at a later stage, showing a rupture in the nuclear membrane, caused very probably by the entrance of the male nucleus. The first sporophyte spindle is being organized within the membrane of the egg-nucleus. June 3 .

Fig. 34. A longitudinal section of an archegonium, showing the position of the first spindle after fertilization. The nuclear membrane has completely disappeared. June 9.

Fig. 35. A more highly magnified view of the spindle shown in Fig. 34. The chromatin-like granules discarded from the egg-cell become associated with kinoplasmic threads as if a second spindle were in process of formation.

Fig. 36. A longitudinal section of the upper half of an archegonium, showing the vacuolated appearance of the cytoplasm caused by the discharge of the contents of the pollen-tubes into the egg. Two distinct male nuclei of unequal size are to be seen accompanied by a much smaller nucleus which is probably the tube-nucleus. June 3 .

Fig. 37. A longitudinal section of an archegonium, showing the first two free nuclei of the proembryo. June 3 .

Fig. 38. Four free nuclei of the pro-embryo have passed to the base of the archegonium.

Fig. 39. Another view of the same.

Fig. 40. A later stage of the pro-embryo, showing the formation of walls between the nuclei.

Fig. 4I. A view of the embryo proper with suspensors.

Fig. 42. Another view of the same, showing the suspensor plug. 
Annals of Botruny.
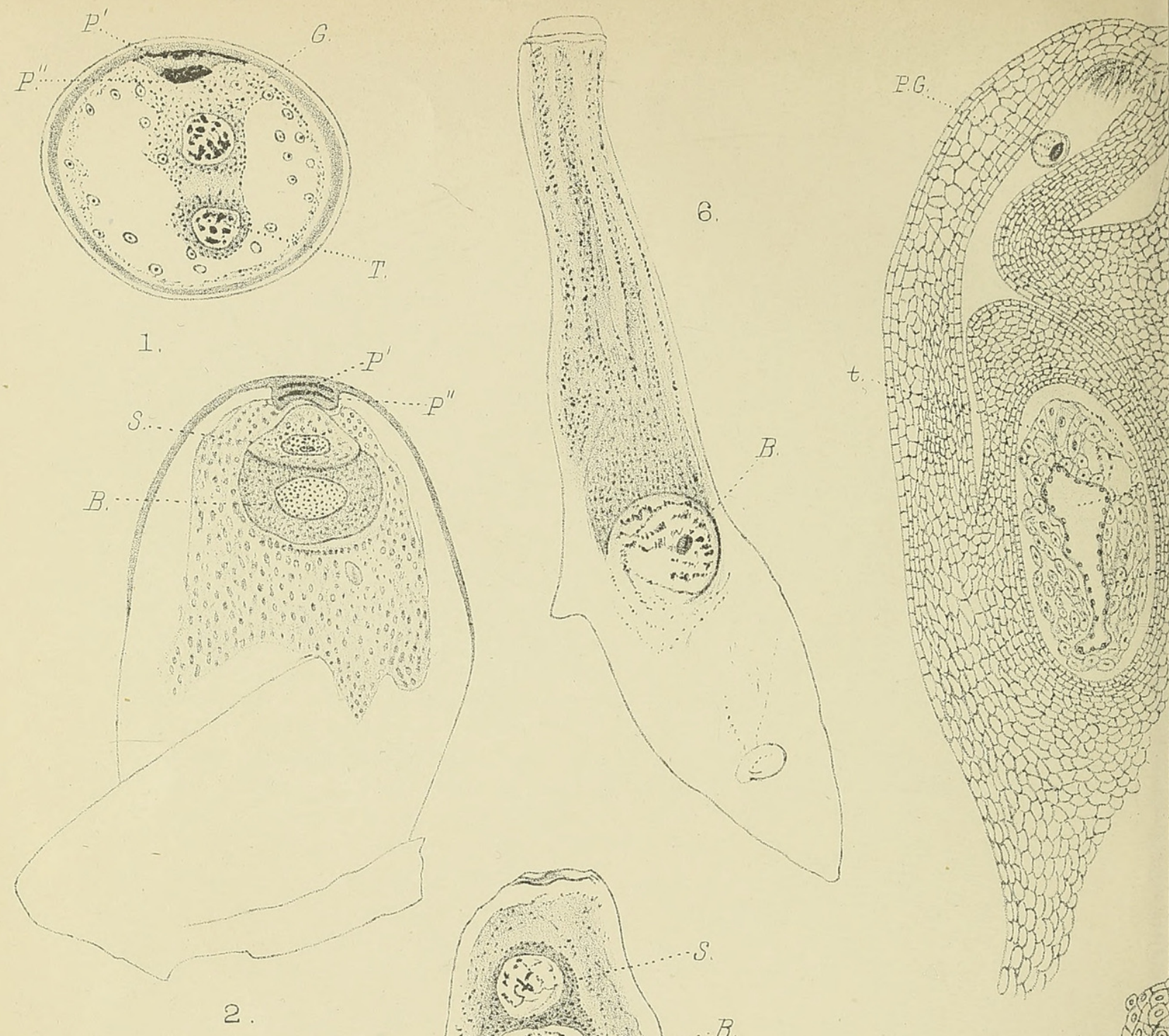

2
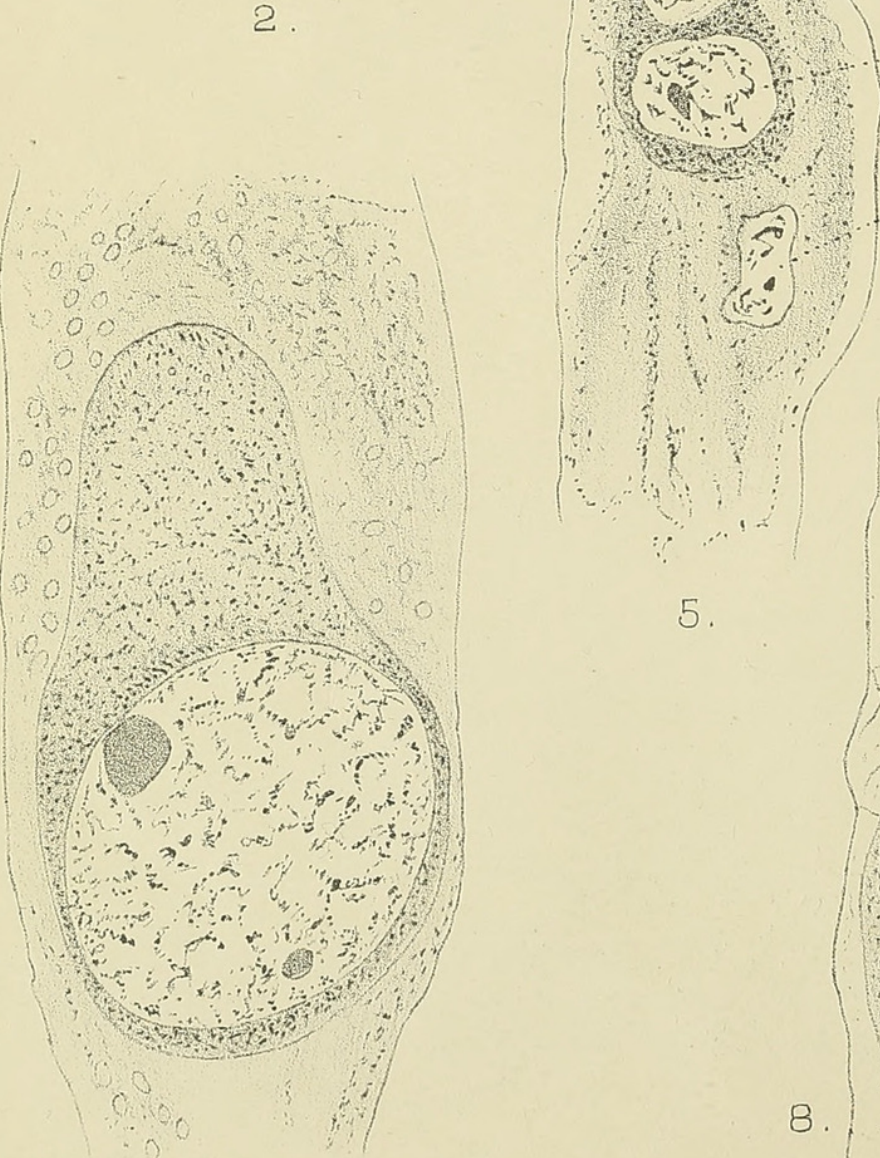

5.
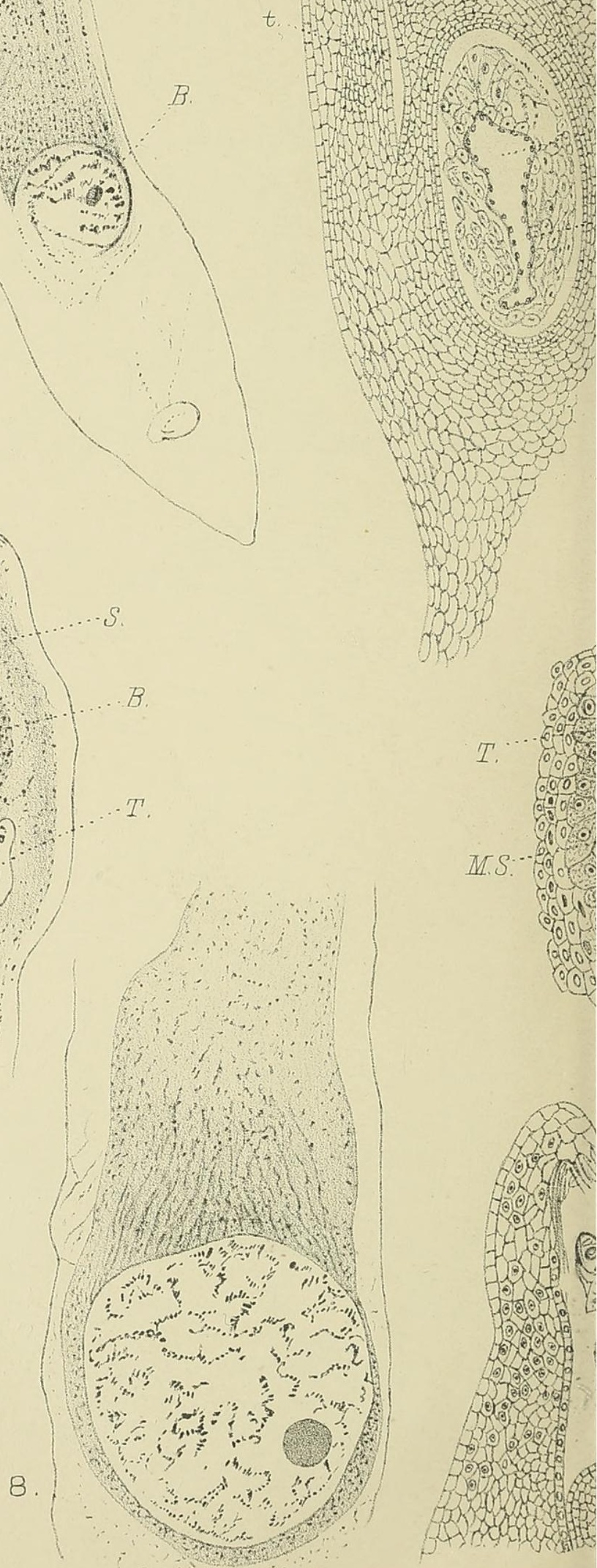

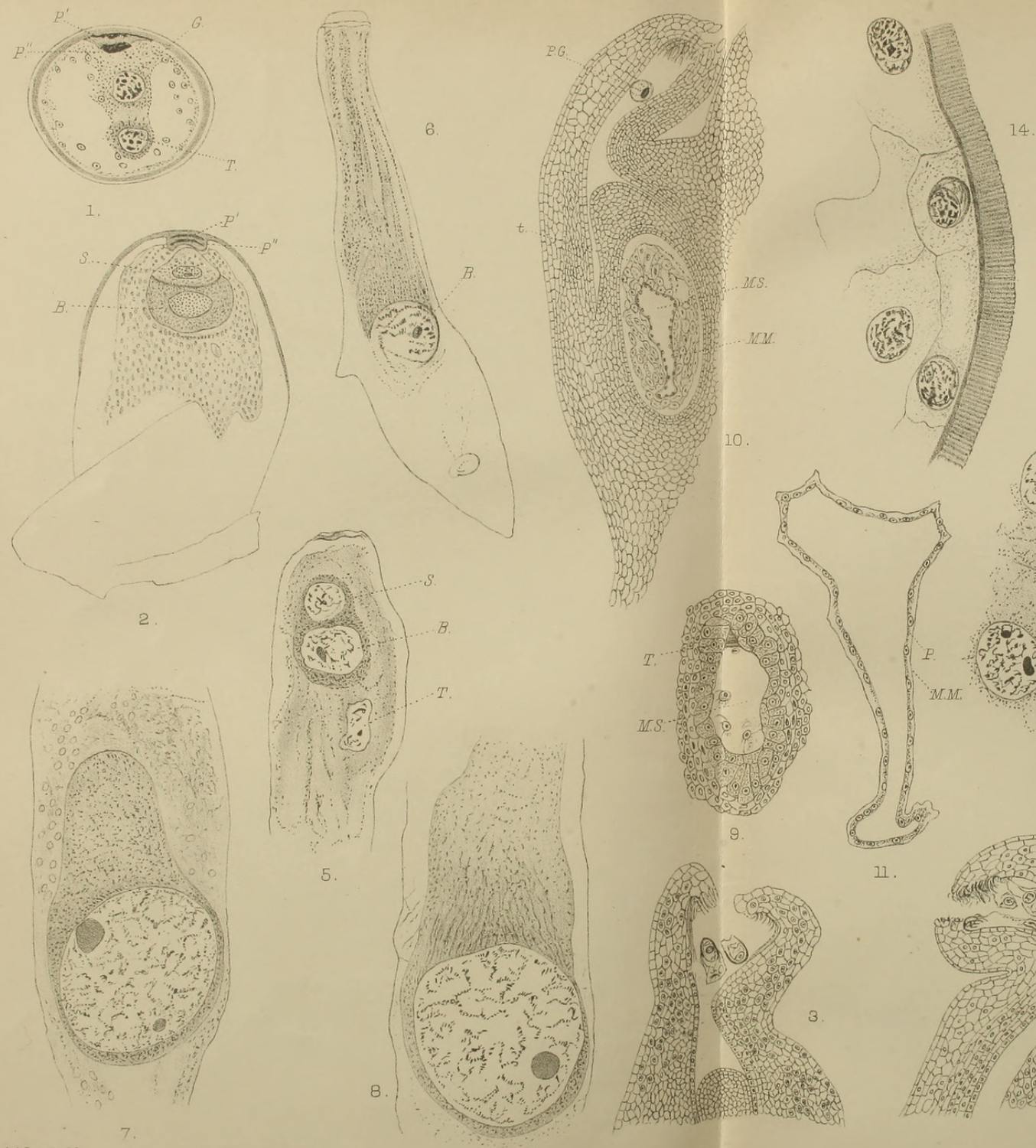

ToL XXIII.PIXII 
Annats of Botany,

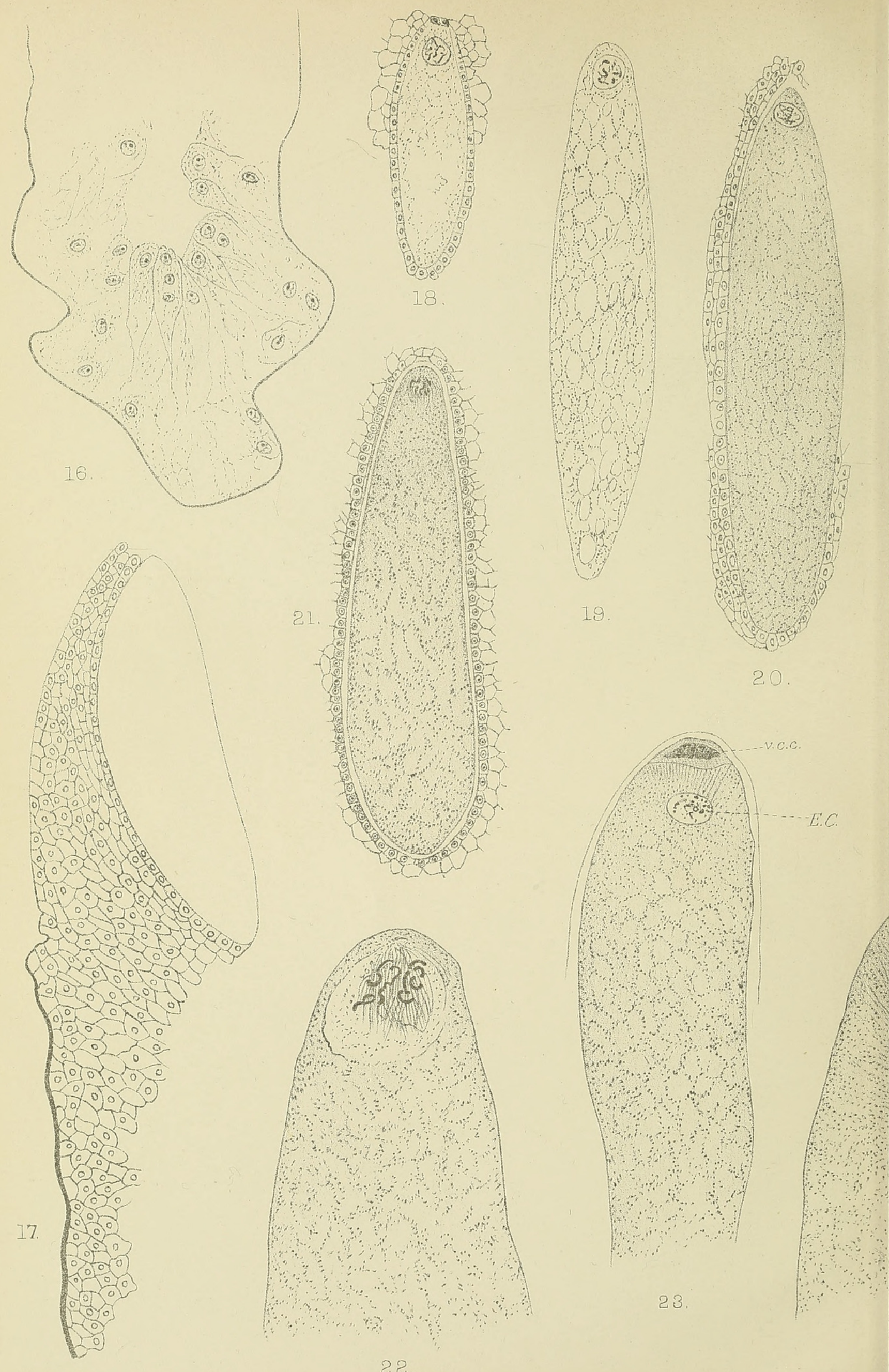


(0.) $01 \%$

(0.00) 0.0 .10

4. $100 \%$. 10.0

(2. $\cdots . .69$

$\because 3 \sqrt{3}$

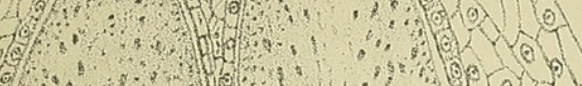

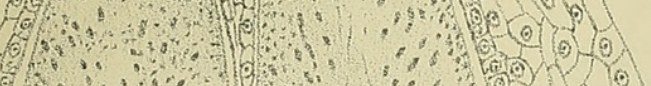

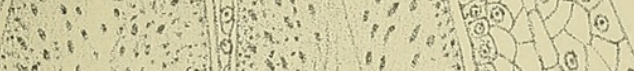

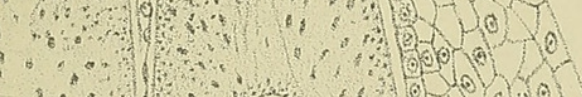

$\therefore \therefore$ a $\therefore$ a 1000

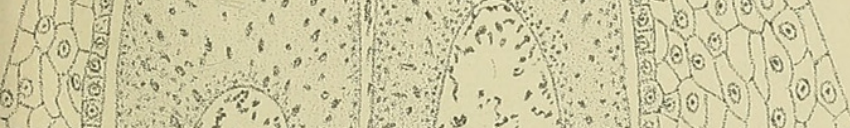

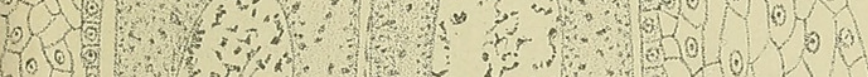

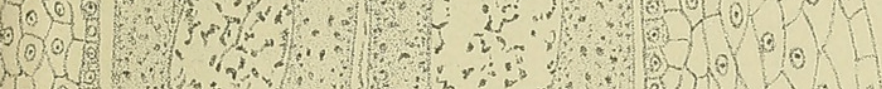

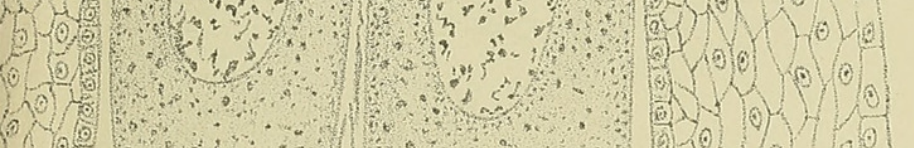

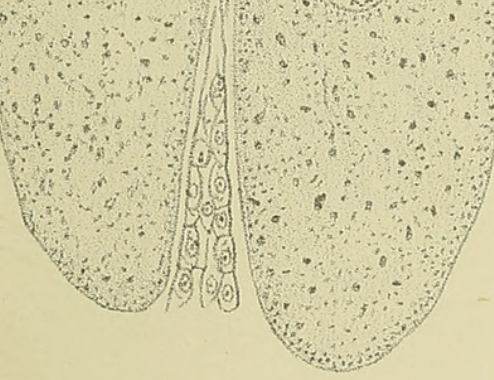

28

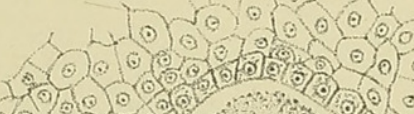

6. $0.0 \%$ की

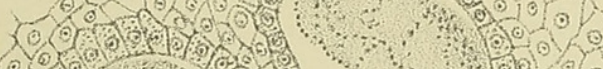

rojar.

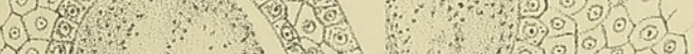

010

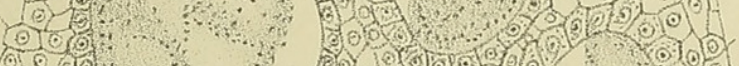

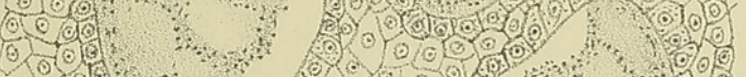

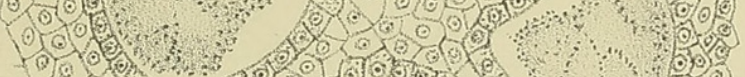

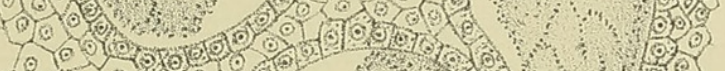

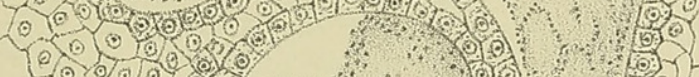

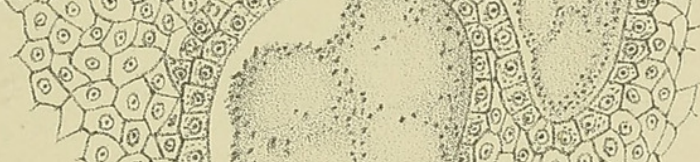

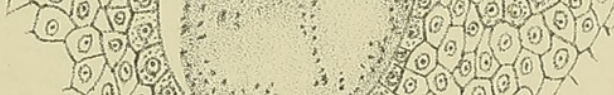

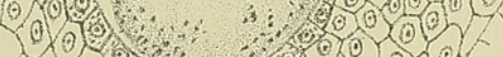
(0) 0 .

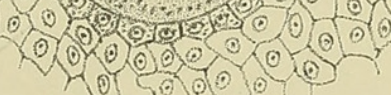

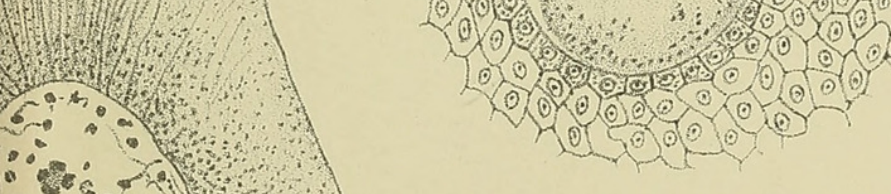

is.

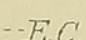

27

25.
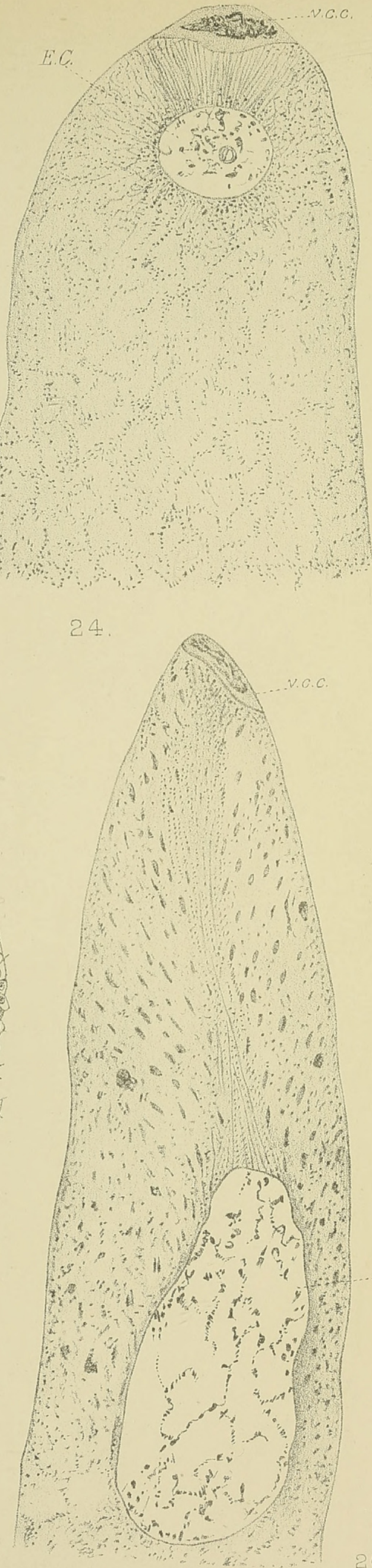

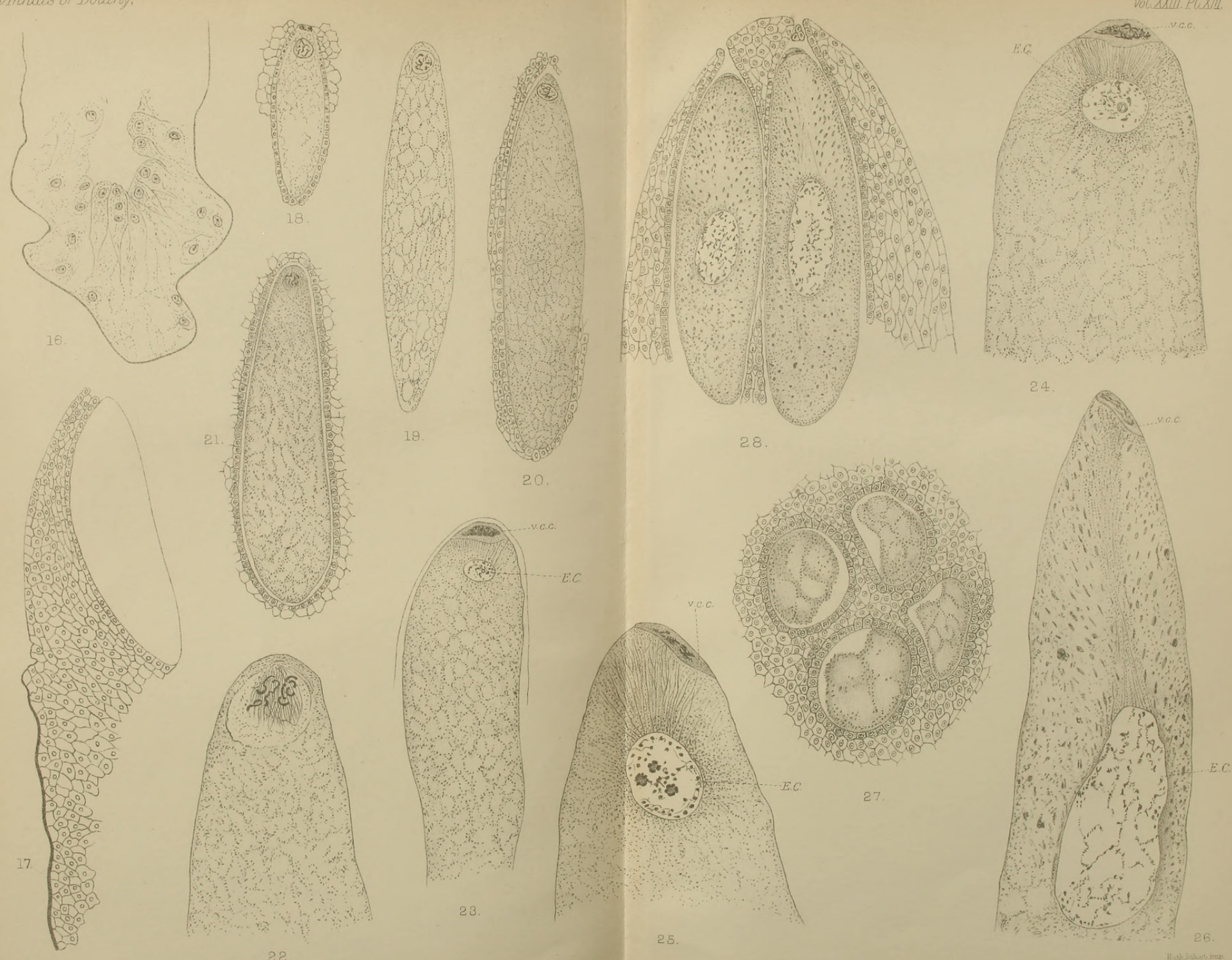
Annals of Botany.
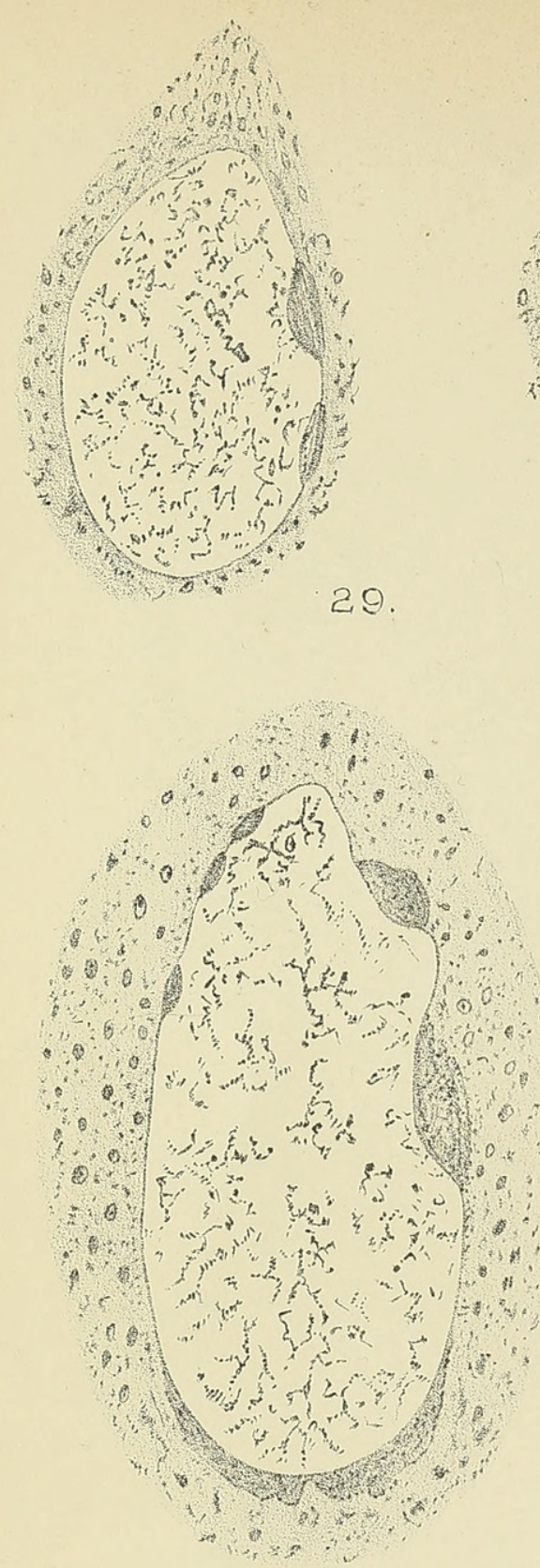

30

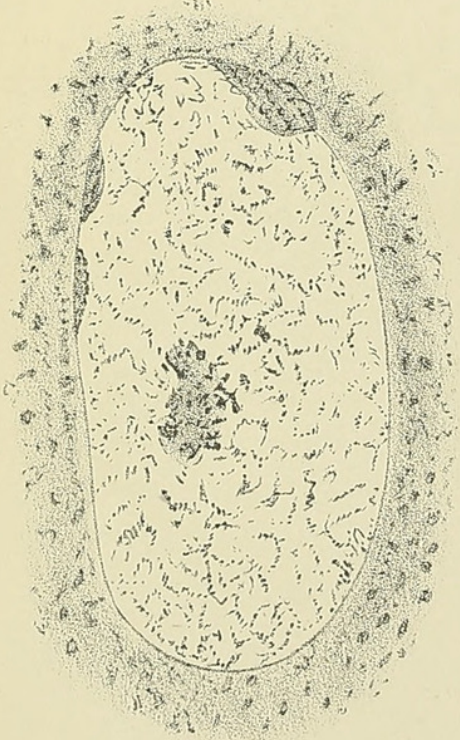

32

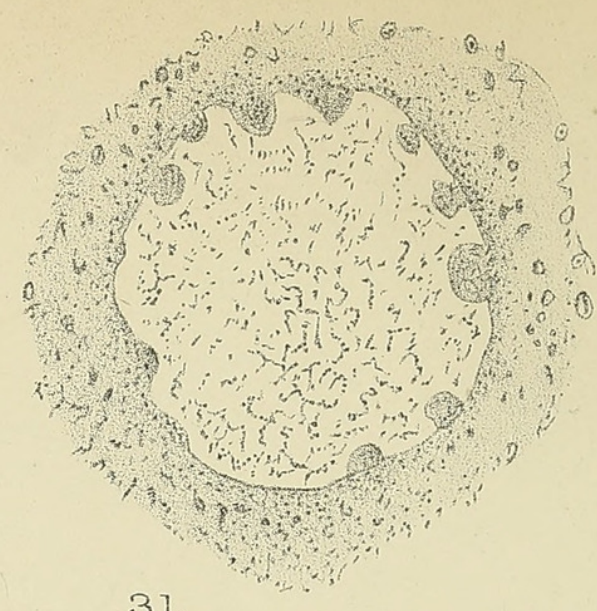

31
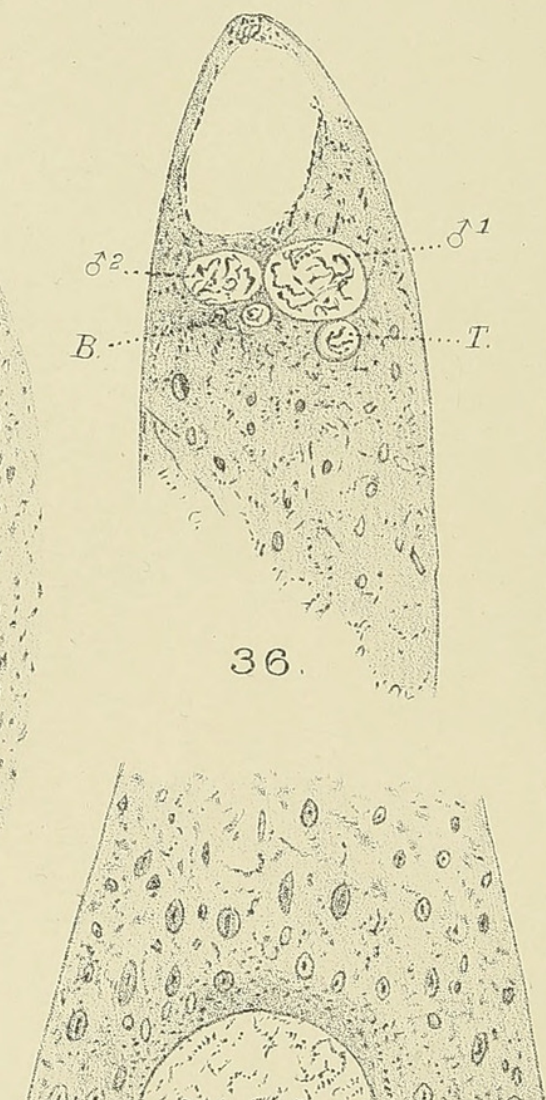

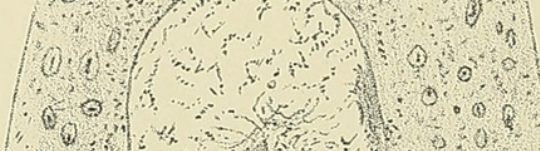
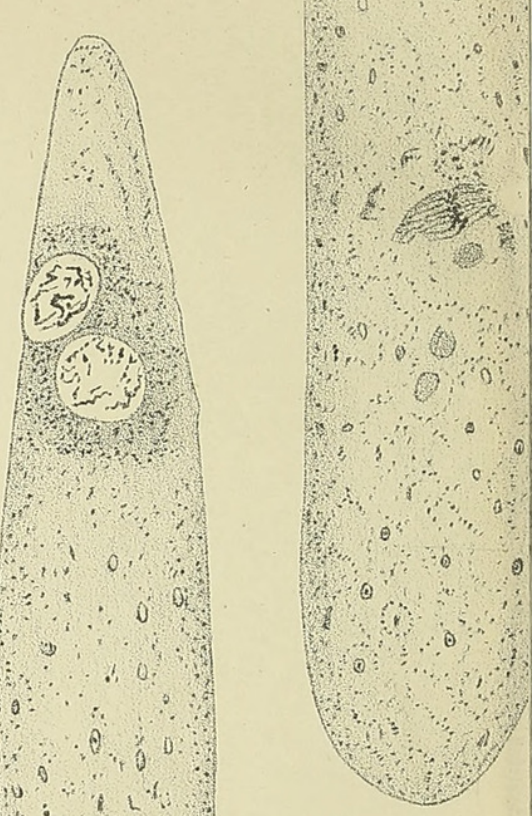

34.

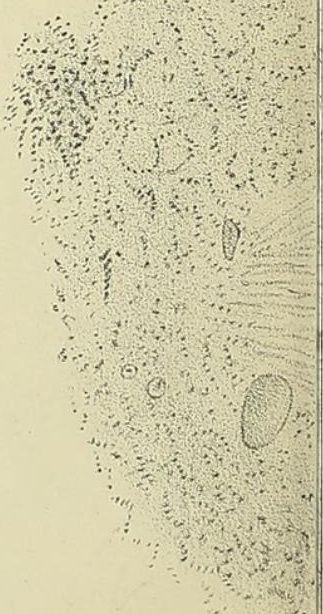

35. 


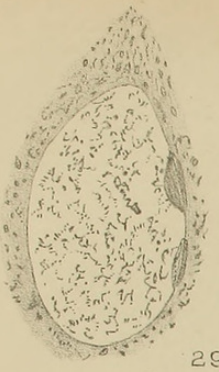

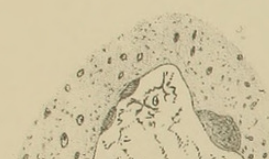
60.0 0003 000430 40040

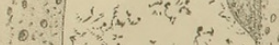

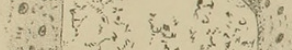

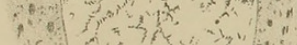

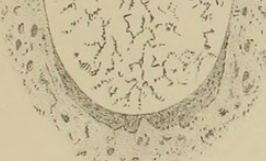

30

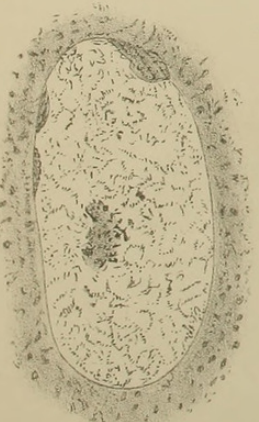

32.

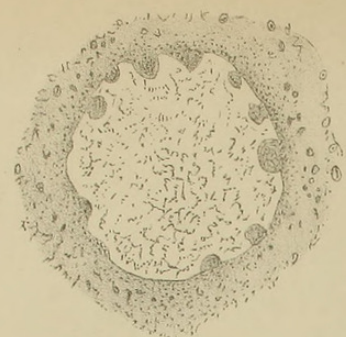

31.

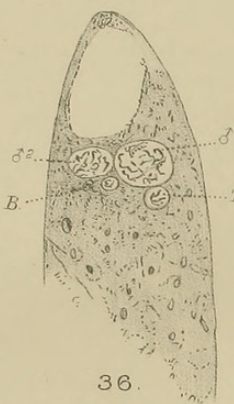

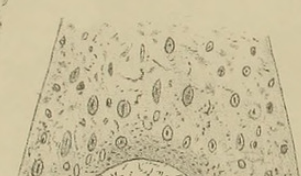
$\therefore 0(1, \quad 7) 00$

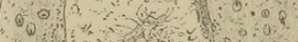

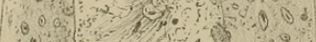
$0 ; 4$ a

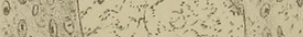

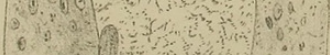

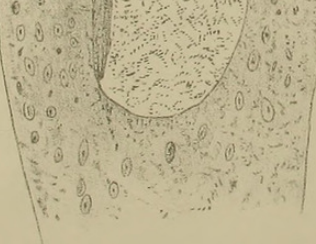

33

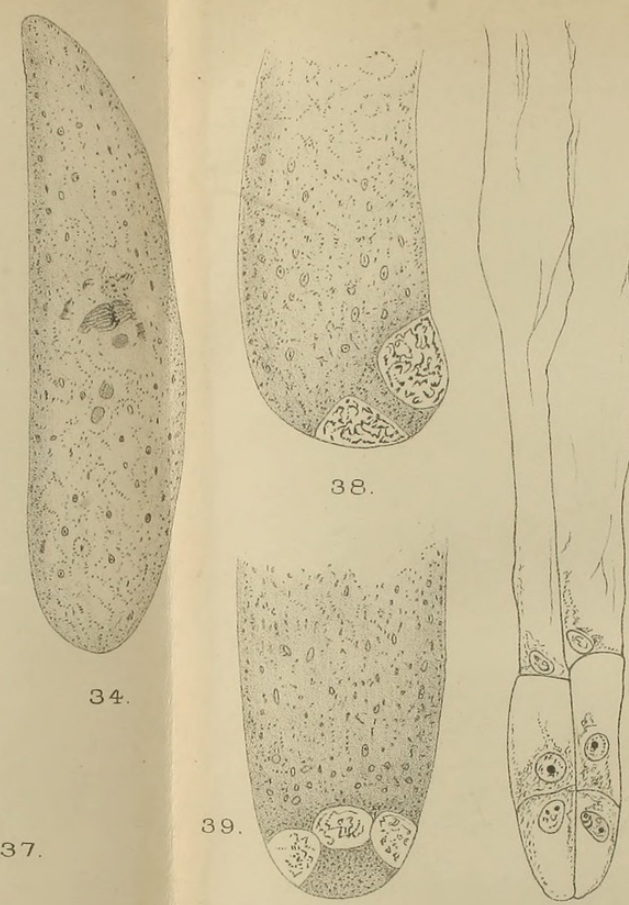

41.

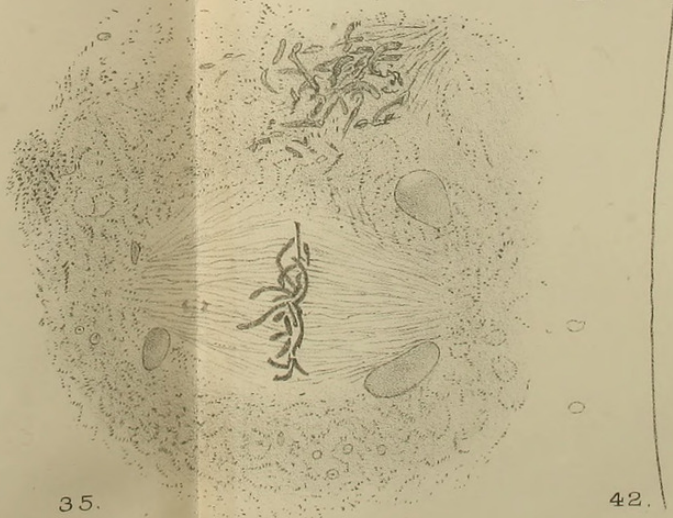

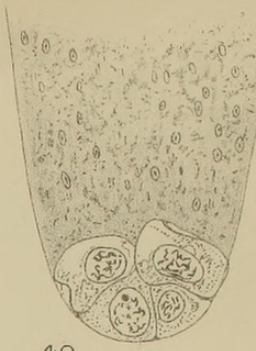

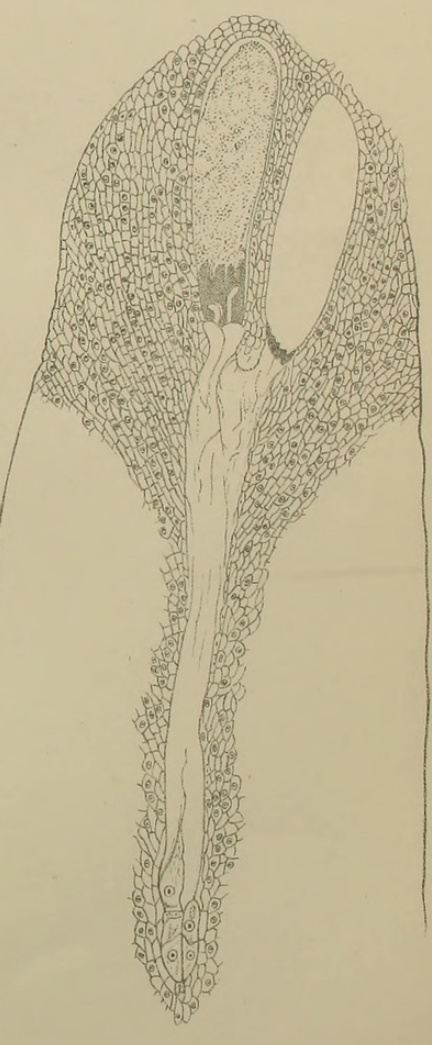




\section{$2 \mathrm{BHL}$ Biodiversity Heritage Library}

Lawson, Abercrombie Anstruther. 1909. "The gametophytes and embryo of Pseudotsuga douglasii." Annals of botany 23, 163-180.

https://doi.org/10.1093/oxfordjournals.aob.a089209.

View This Item Online: https://www.biodiversitylibrary.org/item/236540

DOI: https://doi.org/10.1093/oxfordjournals.aob.a089209

Permalink: https://www.biodiversitylibrary.org/partpdf/318945

\section{Holding Institution}

Smithsonian Libraries

\section{Sponsored by}

Biodiversity Heritage Library

\section{Copyright \& Reuse}

Copyright Status: Not in copyright. The BHL knows of no copyright restrictions on this item.

This document was created from content at the Biodiversity Heritage Library, the world's largest open access digital library for biodiversity literature and archives. Visit BHL at https://www.biodiversitylibrary.org. 